\title{
Motivasi dan Culture Shock Mahasiswa Asing di STAIN Kediri Dalam
}

\section{Lingkungan Budaya Kediri}

\author{
Siti Amanah ${ }^{1}$ \\ amanahsyahdan@yahoo.co.id
}

\begin{abstract}
Abstrak
Penelitian ini bertujuan menganalisis motivasi mahasiswa Thailand belajar di Indonesia dan culture shock yang dialami. Sebagai penelitian deskriptif kualitatif, penentuan subjek penelitian menggunakan teknik purposive sampling dengan informan mahasiswa Thailand STAIN Kediri tahun ajaran 2013/2014, pimpinan STAIN Kediri, dan pihak-pihak lain yang relevan. Data yang digunakan berupa data primer dan data sekunder. Teknik pengumpulan data melalui observasi, wawancara mendalam dan dokumentasi. Analisis data digunakan model analisa data interaktif Miles dan Huberman yang meliputi reduksi data, penyajian data serta penarikan kesimpulan dan verifikasi. Hasil penelitian menyimpulkan bahwa motivasi yang mendorong mahasiswa Thailand belajar ke Indonesia khususnya di STAIN Kediri terdiri dari faktor instrinsik dan ekstrinsik. Faktor intrinsik antara lain: ingin mendapatkan pengalaman baru, ingin belajar bahasa dan budaya Indonesia. Sementara, faktor ekstrinsik meliputi: mendapatkan beasiswa, Indonesia dekat, biaya hidup di Indonesia terjangkau, Indonesia aman \& mayoritas muslim, kesamaan bahasa (rumpun Melayu), pengalaman dari alumni yang pernah belajar di Indonesia. Culture shock dialami oleh mahasiswa Thailand berkaitan dengan makanan, gaya hidup (kebiasaan-kebiasaan, pergaulan), cuaca, dan kegiatan sosial keagamaan. Sebagian besar mahasiswa Thailand berusaha mengatasi culture shock sendiri, lainnya membutuhkan bantuan orang lain seperti teman. Diperlukan proses dan latihan untuk dapat menyesuaikan budaya di Kediri baik terkait dengan cuasa, makanan, bahasa, dan gaya hidup masyarakat setempat. Masing-masing informan membutuhkan masa yang berbeda-beda yakni sekitar satu sampai tiga bulan mereka bisa beradaptasi dan berakulturasi dengan budaya Kediri.
\end{abstract}

Kata Kunci: Culture shock, Indonesia, Mahasiswa, Motivasi, Thailand

\begin{abstract}
This study aims to analyze the motivation of Thai students studying in Indonesia and the culture shock experienced. As a qualitative descriptive research, the determination of research subjects using purposive sampling technique with informants consits of Thai students of STAIN Kediri academic year 2013/2014, head of STAIN Kediri, and other relevant parties. It used primary and secondary data. Data obtained from observation, indepth interviews and documentation. This research used interactive data analysis model Miles and Huberman which include data reduction, data presentation and conclusion and verification. It found that Thai students keen on studying in Indonesia especially in STAIN Kediri motivated by intrinsic and extrinsic factors. Intrinsic factors includes: spirit to gain new experiences, language and culture of Indonesia. Meanwhile, extrinsic factors involves scholarship support, Indonesia is geographycally near to Thailand, cost of living in Indonesia affordable, Indonesia is safe, majority of Muslims population, common language (Melayu), and encouraged by Thai alumni experiences. Culture shock experienced by Thai students
\end{abstract}

${ }^{1}$ Korespondensi: Siti Amanah. Jurusan Ushuluddin, Dakwah, dan Komunikasi STAIN Kediri. Jalan Sunan Ampel No.7, Ngronggo, Kecamatan Kota Kediri, Rejomulyo, Kec. Kota Kediri, Kediri, Jawa Timur 64129. Telp. 082140978479 
related to the matter of food, lifestyle, habits, weather, and social activities. Most of Thai students try to overcome their own culture shock, yet others need friends to help. It takes process and practice in recognizing culture of Kediri in terms of local food, language, and lifestyle. Each informant requires a different period of about one to three months.

Keywords: Culture shock, Indonesia, Motivation, Student, Thailand

\section{Pendahuluan}

Di era globalisasi, pergaulan antarbangsa semakin ketat. Batas antarnegara hampir tidak ada artinya. Batas wilayah tidak lagi menjadi penghalang. Dengan berkembangnya teknologi dan era globalisasi mendorong manusia untuk berinteraksi dengan orang lain di belahan dunia yang memiliki latar belakang budaya berbeda. Perkembangan globalisasi yang menempatkan ideologi multikultural semakin eksis. Komunikasi menjadi kajian yang sangat penting di masyarakat multikultural ini, mengingat komunikasi diperlukan untuk menciptakan harmoni pada masyarakat multikultural saat berinteraksi satu sama lain. Betapa pentingnya komunikasi ini terlihat dari semakin inovatifnya perkembangan teknologi komunikasi itu sendiri. Kemajuan teknologi komunikasi bisa mengaburkan batas-batas geografis atau wilayah. Ras, suku, agama, latarbelakang sosial, pendidikan, warna kulit, dan sebagainya merupakan realitas yang tidak dapat dihindarkan. Sebagai makhluk sosial, manusia, manusia tidak hanya melakukan interaksi sebatas pada mereka yang memiliki kesamaan saja.Apalagi di era global saat ini di mana mulai dari alat transportasi dan alat komunikasi dan informasi menjembatani perbedaan geografis (Nasrullah: 2014).

Mobilitas penduduk dunia yang semakin tinggi dan kemajuan teknologi komunikasi yang berkembang pesat juga semakin memungkinkan terjadinya komunikasi antar budaya. Perbedaan kultur dari orang - orang yang berkomunikasi yang menyangkut kepercayaan, nilai, serta cara berperilaku serta latar belakang budaya yang berbeda inilah yang menjadi ciri terpenting yang menandai komunikasi antar budaya.

Dalam rangka mengemban visi global ini STAIN Kediri telah melakukan kerjasama dalam bentuk program pertukaran belajar dan pengembangan dakwah dengan Badan Alumni Internasional, Majelis Tinggi Agama Islam Thailand Selatan. Kerjasama STAIN Kediri dengan Badan Alumni Internasional Thailand serta Majelis 
Tinggi Agama Islam Pattani Thailand Selatan didasarkan atas beberapa pemikiran kerjasama yang saling menguntungkan kepentingan 2 (dua) bangsa yang berbeda dalam satu rumpun Ras Melayu dan sesama agama yakni agama Islam.

Program tersebut digagas pada mulanya sebagai kelanjutan dari pelaksanaan seminar pengembangan dakwah Islam rahmatan lil'alamin bagi bangsa di kawasan Asia Tenggara. Dasar pemikiran program ini bermuara pada pengembangan dakwah Islam rahmatan lil'alamin lewat pengembangan pendidikan. Berkat kerjasama tersebut telah menerima mahasiswa Thailand angkatan pertama pada tahun 2013 sebanyak 10 mahasiswa dan dilanjutkan tahun 2014, dan Pihak Thailand telah memberikan kesempatan kepada mahasiswa STAIN Kediri untuk melakukan praktik lapangan mengajar selama satu semester tiap tahun dalam rangka memenuhi tuntutan guru secara instan.

Kemajuan transportasi juga membuat manusia bisa menempuh jarak ribuan mil dalam waktu hitungan jam saja sehingga perpindahan atau mobilitas manusia juga semakin mudah. Namun kemudahan ini bukan tanpa konsekuensi karena kemudahan mobilitas bukan berarti terjadi kemudahan pertemuan budaya. Orang yang sudah puluhan tahun dalam hidup sebuah budaya tidak mungkin serta merta merubah budaya dan kebiasaannya hanya karena dia telah berpindah tempat. Demikian juga halnya para peserta didik dari Thailand tidak dengan begitu saja bisa mengganti budaya asal dengan budaya baru.

Menuntut ilmu di negeri orang bagi sebagian orang merupakan tantangan tersendiri. Namun dengan mengikuti program pendidikan di Perguruan Tinggi seperti ini akan memberikan kesempatan untuk bisa belajar tentang bahasa, budaya serta pengalaman hidup yang sangat berharga bagi calon mahasiswa yang mengikutinya. Belajar di kampus yang mengedepankan nilai-nilai islami, STAIN Kediri banyak menawarkan hal yang menarik dan layak untuk diungkap lebih jauh, karena mahasiswa asing dari Thailand mengalami berbagai pengalaman yang berkaitan dengan komunikasi dan benturan budaya. Sehingga menarik untuk menganalisis motivasi mahasiswa Thailand belajar ke Indonesia khususnya di STAIN Kediri dan bagaimana mahasiswa mengalami culture shock berada di lingkungan Kediri serta upaya adaptasinya. 
Penelitian ini diharapkan dapat memperkaya khasanah ilmu pengetahuan khususnya pada pengembangan komunikasi lintas budaya khususnya berkaitan dengan pola komunikasi lintas budaya dan akulturasi budaya Indonesia. Lebih jauh, penelitian ini diharapkan bermanfaat khususnya bagi mahasiswa STAIN Kediri dan seluruh pembaca untuk bisa memahami budaya lain dan memudahkan proses adaptasi jika harus berinteraksi dengan budaya yang berbeda sehingga memunculkan toleransi di antara partisipan komunikasi yang berbeda budaya. Dalam hal ini penulis meyakini bahwa pemahaman tentang komunikasi lintas budaya mampu menciptakan keharmonisan dan toleransi dalam kehidupan sosial berbagai elemen masyarakat.

\section{Tinjauan Pustaka}

\section{Motivasi}

Sesuatu yang bisa memberi dorongan kepada seseorang untuk melakukan suatu tindakan bisa disebut dengan motivasi. Seperti yang diungkapkan oleh Wahjosumidjo, motivasi merupakan "suatu proses psikologis yang mencerminkan interaksi antara sikap, kebutuhan, persepsi dan keputusan yang terjadi pada diri seseorang” (Wahjosumidjo, 1994:174). Motivasi ini bisa disebabkan oleh faktor dari dalam diri seseorang yang disebut dengan faktor intrinsik misalnya berupa kepribadian, sikap, pengalaman dan pendidikan atau berbagai harapan, cita-cita yang menjangkau masa depan. Sedangkan motivasi yang disebabkan oleh faktor dari luar diri seseorang disebut faktor ekstrinsik. Faktor ini dapat ditimbulkan oleh berbagai sumber bisa karena pengaruh pemimpin, kolega atau faktor-faktor lain yang sangat kompleks.

Motivasi yang kuat maka seseorang akan terdorong untuk lebih kuat melakukan sesuatu atau mengambil sikap tertentu. Motivasi bisa ditumbuhkan melalui pemberian hadiah, pujian, rasa kebanggaan pribadi, atau rasa kedaerahan, kebangsaan dan sebagainya. Motivasi sangat diperlukan dalam usaha menumbuhkan dan meningkatkan partisipasi masyarakat dalam pembangunan (Priyatna, 1996:15). Menurut W.I Thomas dan Florian ada beberapa motif sosiogenis yang membentuk perilaku manusia yaitu: 1. Keinginan memperoleh pengalaman baru; 2. Keinginan mendapatkan respon; 3. Keinginan akan pengakuan dan 4. Keinginan akan rasa aman (Rakhmat, 2005:37). 


\section{Memahami Komunikasi Antarbudaya}

Samovar dan Porter menyatakan budaya tidak dapat dipisahkan dari komunikasi. Konsekuensinya, budaya merupakan landasan komunikasi. Bila budaya beraneka ragam, maka beraneka ragam pula praktik-praktik komunikasi. Komunikasi antarbudaya terjadi bila produsen pesan adalah anggota suatu budaya dan penerima pesannya adalah anggota suatu budaya lainnya (Mulyana dan Rakhmat, 2006:19). Dalam bukunya, Intercultural Communication (1991), Samovar menyatakan bahwa hubungan antara kebudayaan dan komunikasi bersifat resiprokal. Artinya tidak dapat dipisahkan sehingga masing-masing bidang saling berkaitan dan saling pengaruh mempengaruhi serta saling menentukan satu dengan yang lain. "Culture cannot exist without communication, one cannot change without cousing change in the other" (Purwasito, 2003).

Komunikasi budaya menurut Samovar dan Porter dimaknai sebagai komunikasi antarbudaya terjadi antara produsen pesan dan penerima pesan yang latar belakang kebudayaannya berbeda. Komunikasi antarbudaya oleh Fred E. Jandt, diartikan sebagai interaksi tatap muka di antara orang-orang yang berbeda budayanya (intercultural communication generally refers to face-to-face interaction among people of diverse culture). Sedangkan Collier dan Thomas sebagaimana dikutip Jandt, mendefinisikan komunikasi antarbudaya sebagai "as communication between persons who identity themselves as distinct from "other in a cultural sense" (Purwasito, 2003:122-123)

\section{Variabel- variabel Komunikasi Antarbudaya}

Variabel-variabel komunikasi antarbudaya menurut Young Yun Kim (dalam Mulyana dan Rakhmat, 2006:141 -144) adalah sebagai berikut; 1)Komunikasi Persona. Komunikasi persona atau intrapersona mengacu pada proses-proses mental yang dilakukan orang untuk mengatur dirinya sendiri dalam dan dengan lingkungan sosio-budayanya, mengembangkan cara-cara melihat, mendengar, memahami, merespons lingkungan. 2) Komunikasi Sosial. Komunikasi sosial dapat dikategorikan lebih jauh ke dalam komunikasi antarpersona dan komunikasi massa. 3) Lingkungan Komunikasi Komunikasi persona dan komunikasi sosial seorang imigran dan fungsi 
komunikasi-komunikasi tersebut tidak dapat sepenuhnya dipahami tanpa dihubungkan dengan lingkungan komunikasi masyarakat pribumi. Suatu kondisi lingkungan yang sangat berpengaruh pada komunikasi dan akulturasi imigran adalah adanya komunitas etniknya di daerah setempat.

\section{Culture Shock}

Menurut Furnham dan Bochner, "culture shock adalah ketika seseorang mengenal kebiasaan-kebiasaan sosial dari kultur baru atau jika ia mengenalnya maka ia tidak dapat atau tidak bersedia menampilkan perilaku yang sesuai dengan aturanaturan itu". Sementara itu Kalvero Oberg menyatakan bahwa culture shock (gegar budaya) ditimbulkan oleh kecemasan yang disebabkan oleh kehilangan tanda-tanda dan lambang-lambang dalam pergaulan sosial. Tanda-tanda tersebut meliputi seribu satu cara yang kita lakukan dalam mengendalikan diri sendiri dalam menghadapi situasi sehari-hari. Petunjuk-petunjuk ini yang mungkin dalam bentuk-bentuk katakata, isyarat-isyarat, ekspresi wajah, kebiasaan-kebiasaan, atau norma-norma, kita peroleh sepanjang perjalanan hidup sejak kecil. Bila seseorang memasuki suatu budaya asing, semua atau hampir semua petunjuk ini lenyap (Mulyana dan Rakhmat, 2006:174).

Culture shock biasanya dipicu oleh salah satu atau lebih dari tiga penyebab (Dayakisni dan Yuniardi, 2008:187) antara lain: 1) Kehilangan clues atau tanda-tanda yang dikenalnya. Padahal clues adalah bagian dari kehidupan sehari-hari seperti tandatanda, gerakan bagian-bagian tubuh (gestures), ekspresi wajah ataupun kebiasaankebiasaan yang dapat menceritakan kepada seseorang bagaimana sebaiknya bertindak dalam situasi-situasi tertentu. 2) Putusnya komunikasi antar pribadi baik pada tingkat yang disadari maupun tidak disadari yang mengarahkan pada frustasi dan kecemasan. Halangan bahasa adalah penyebab jelas dari gangguan-gangguan ini. 3) Krisis identitas, dengan pergi keluar negeri seseorang akan kembali mengevaluasi gambaran tentang dirinya.

\section{Akulturasi Budaya}

Akulturasi (acculturation) adalah proses sosial yang timbul bila suatu kelompok manusia dengan suatu kebudayaan tertentu dihadapkan dengan unsur- 
unsur kebudayaan dari suatu kebudayaan asing yang sedemikian rupa, sehingga unsur-unsur kebudayaan asing itu lambat laun diterima dan diolah ke dalam kebudayaan sendiri tanpa menyebabkan hilangnya kepribadian kebudayaan sendiri. Proses akulturasi ini erat kaitanya dengan asimilasi karena keduanya merupakan proses lanjutan dari akomodasi. Menurut Syahrial Syarbaini dan Rusdiyanta dalam buku dasar-dasar sosiologi bahwa pada proses asimilasi terjadi proses peleburan kebudayaan sehingga pihak-pihak dari berbagai kelompok yang tengah berasimilasi akan merasakan kebudayaan tunggal yang dirasakan milik bersama. Proses asimilasi ditandai adanya usaha-usaha mengurangi berbagai perbedaan yang terdapat antara orang perorangan atau kelompok-kelompok manusia dan juga meliputi usaha-usaha untuk mempertinggi kesatuan tindak, sikap-sikap dan proses-proses mental dengan memperhatikan kepentingan-kepentingan dan tujuan-tujuan bersama (Syarbaini dan Rusdiyanta, 2009:30).

Potensi akulturasi seorang imigran sebelum berimigrasi dapat mempermudah akulturasi yang dialaminya dalam masyarakat pribumi. Potensi akulturasi menurut Young Yun Kim (dalam Mulyana dan Rakhmat, 2006:145) ditentukan oleh faktor-faktor berikut: 1) Kemiripan. Kemiripan antara budaya asli (imigran) dan budaya pribumi mungkin merupakan faktor terpenting yang menunjang potensi akulturasi. 2) Usia pada saat berimigrasi. Di antara faktor-faktor atau karakteristik-karakteristik demografik, usia pada saat berimigrasi dan latar belakang pendidikan terbukti berhubungan dengan potensi akulturasi. 3) Latar belakang pendidikan. Latar belakang pendidikan imigran sebelum berimigrasi mempermudah. Pendidikan terlepas dari konteks budayanya, ternyata memperbesar kapasitas seseorang untuk menghadapi pengalaman baru dan mengatasi tantangan hidup. 4) Kepribadian. Faktor-faktor lain yang memperkuat potensi akulturasi adalah faktor-faktor kepribadian seperti suka berteman, toleransi, mau mengambil resiko, keluwesan kognitif, keterbukaan dan sebagainya. Karakteritik-karakteristik kepribadian ini bisa membantu imigran membentuk persepsi, perasaan dan perilakunya yang memudahkan dalam lingkungan yang baru. 5) Pengetahuan, Penggetahuan imigran tentang budaya pribumi sebelum berimigrasi yang diperoleh dari kunjungan sebelumnya, kontak-kontak antarpersona, dan lewat media massa, juga dapat mempertinggi potensi akulturasi imigran. 


\section{Metode}

Penelitian ini menggunakan metode deskriptif kualitatif. Pengertian deskripsi kualitatif adalah "studi yang mengarah pada pendeskripsian secara rinci dan mendalam mengenai potret kondisi tentang apa yang sebenarnya terjadi menurut apa adanya di lapangan studinya" (Sutopo, 2002:109). Sementara itu Bogdan dan Taylor mendefinisikan metode kualitatif dianggap sebagai "prosedur penelitian yang menghasilkan data deskriptif berupa kata-kata tertulis atau lisan dari orang-orang dan perilaku yang dapat diamati” (Moelong, 2001:3). Penelitian ini dilakukan pada Sekolah Tinggi Agama Islam Negeri (STAIN) Kediri pada tahun 2014. Penentuan lokasi penelitian tersebut berdasarkan pertimbangan bahwa pada tahun ajaran 2013/2014 STAIN Kediri menerima mahasiswa baru dari Thailand yang berasal dari Pattani -Thailand bagian selatan.

Sumber data dalam penelitian ini terdiri atas data primer dan data sekunder. Data primer adalah data yang peneliti peroleh secara langsung di lapangan dengan cara wawancara dengan informan di lokasi penelitian. Informan dipilih dengan menggunakan teknik purposive sampling. Data primer penelitian adalah Mahasiswa Thailand TA. 2013/2014 yang sedang menempuh pendidikan di STAIN Kediri. Selain itu juga informan lainnya seperti mahasiswa yang telah mengikuti program KKN di Thailand, Ketua STAIN Kediri yang mengetahui latar belakang program kerjasama antara pihak Thailand dengan STAIN Kediri tahun 2013, dan pihak-pihak lain yang terkait dengan penelitian ini. Sumber data sekunder penelitian di antaranya adalah dokumen-dokumen yang berkaitan dengan penelitian seperti buku-buku, arsip dan sumber pustaka lainnya.

Teknik pengumpulan data yang digunakan dalam penelitian ini adalah: wawancara mendalam (In-depth interviewing); observasi; mencatat dokumen (content analysis). Teknik analisis data dalam penelitian ini adalah dengan menggunakan model analisis interaktif. Menurut Miles \& Huberman, model analisis interaktif ini ada tiga komponen analisisnya yaitu reduksi data, sajian data, dan penarikan simpulan/verifikasinya, aktivitasnya dilakukan dalam bentuk interaktif dengan proses pengumpulan data sebagai suatu proses siklus (Sutopo, 2002:91). Tiga alur kegiatan 
tersebut ialah reduksi data, penyajian data, dan penarikan simpulan (Koentjaraningrat, 1986:269).

Dalam penelitian, validitas atau pemantapan dan kebenaran informasi dapat dicapai dengan beberapa jenis trianggulasi yang merupakan cara umum digunakan bagi peningkatan validitas dan dalam penelitian ini menggunakan trianggulasi data atau trianggulasi sumber. Selain itu juga menggunakan reviu informan sebagai upaya pengembangan validitas dalam penelitian ini. Menurut Sutopo (2002:83), hal ini dilakukan oleh peneliti ketika "sudah mendapatkan data yang cukup lengkap maupun berusaha menyusun sajian data maka unit-unit laporannya dikomunikasikan kepada informannya (khususnya key informant)". Kegiatan ini dilakukan agar tercapai kesamaan pemahaman antara peneliti dengan informan. Sementara itu untuk mengetahui derajat kepercayaan (credibility) yakni kesesuaian antara konsep peneliti dengan konsep responden, maka peneliti melakukan peer debriefing yakni hasil kajian didiskusikan dengan orang lain misalnya dengan peneliti lain atau para ahli lain yang memiliki pengetahuan tentang pokok penelitian dan metodologi yang diterapkan.

Kerjasama program pertukaran belajar dan pengembangan Dakwah antara STAIN Kediri dan Badan Alumni Internasional, Majelis Tinggi Agama Islam Thailand Selatan merupakan capaian kedua belah pihak yang saling menguntungkan. Pada tahun 2013 Sekolah Tinggi Agama Islam Negeri (STAIN) Kediri menerima mahasiswa baru dari Thailand sebanyak 10 orang. Dalam penelitian ini, karakteristik informan dibagi dalam beberapa kategori berdasarkan tempat tinggalnya di Thailand, jenis kelamin, usia, dan program studi yang ditekuninya selama belajar di STAIN Kediri. Berdasarkan tempat asalnya di Thailand yaitu: 50\% berasal dari Songkhla Thailand; 40\% dari Pattany; dan 10\% dari Narathiwat. Ketiga wilayah tersebut termasuk wilayah Thailand Selatan di mana secara sosiologis terdiri dari etnis Melayu yang lebih dari $85 \%$ penduduknya memeluk agama Islam, dan wilayah ini relatif tertinggal. 
Tabel 1. Distribusi informan berdasarkan tempat tinggalnya di Thailand

\begin{tabular}{c|c|c|c} 
No & Asal (tempat tinggalnya) & Jumlah (jiwa) & Persentase $(\%)$ \\
\hline 1 & Songkhla Thailand & 5 & 50 \\
\hline 2 & Pattany & 4 & 40 \\
\hline 3 & Narathiwat & 1 & 10 \\
\hline & Jumlah & & 100
\end{tabular}

Berdasarkan jenis kelamin informan terbagi dalam 2(dua) kategori yaitu laki-laki dan perempuan. Subjek penelitian yakni mahasiswa dari Thailand yang berjenis kelamin laki-laki sebanyak 6 orang atau $60 \%$ dan 4 orang berjenis kelamin perempuan atau $40 \%$. Berdasarkan usia informan terbagi dalam 2 kategori yaitu usia antara $20-24$ tahun dan 25 - 29 tahun. Informan usia 20 - 24 tahun sebanyak $80 \%$ atau 8 orang dan berusia 25-30 tahun sebanyak 20\% atau 2 orang. Mahasiswa Thailand angkatan TA.2013/2014 memilih program studi yang beragam sesuai dengan minatnya masingmasing. Mahasiswa Thailand yang belajar dii Jurusan Tarbiyah pada program studi Pendidikan Bahasa Arab (PBA) sebanyak 20\% atau 2 orang, yang memilih di Program Studi Pendidikan Agama Islam (PAI) sebanyak 2 orang atau 20\%; sebanyak 40\% memilih belajar di Program Studi Tadris Bahasa Inggris (TBI); dan di Jurusan Syariah sebanyak 10\% memilih di Program Studi Ekonomi Islam (EI) dan sebanyak 10\% menekuni belajar di Program Studi Ahwalus Syakhsiyah (AS).

\section{Hasil dan Pembahasan}

\section{Motivasi Mahasiswa Thailand Belajar di STAIN Kediri - Indonesia}

Mahasiswa Thailand ini masuk pada tahun ajaran 2013/2014. Semua menempuh program strata $1(\mathrm{~S} 1)$ yaitu selama empat tahun. Sebelum berangkat ke Indonesia terdapat rangkaian kegiatan yang harus mereka jalani. Diantaranya test di masing-masing sekolah asal. Selanjutnya akan dipilih nama-nama yang lulus dalam test tersebut. Dari hasil wawancara ternyata semua mahasiswa Thailand tidak mengenal satu sama lain dikarenakan berasal dari sekolah yang berbeda, dan masingmasing sekolah hanya satu yang dipilih untuk masuk ke STAIN Kediri. Setelah serangkaian test dilalui dilanjutkan dengan pemenuhan persyaratan berupa syarat kelulusan dari sekolah (Aliyah dan SMA), passport, visa, dan surat kesehatan. Dalam perjalanan menuju ke Indonesia, mereka sudah mendapat fasilitas berupa mobil travel 
untuk menjemput di rumah masing-masing. Selanjutnya perjalanan menuju ke masjid besar di Pattani untuk berkumpul. Kemudian berangkat dari Kuala Lumpur Airport jam 9.00WIB hingga tiba di Surabaya jam 11.00 WIB. Dari Bandara mereka dijemput oleh pihak kampus STAIN Kediri menggunakan bus STAIN Kediri.

Beragam alasan seseorang bisa pergi keluar negeri. Keinginan mahasiswa Thailand mengikuti program studi di Indonesia khususnya di STAIN Kediri adalah ketika ada informasi dari pihak sekolah asal (setingkat dengan SMA dan MA) di Thailand. Pada waktu itu semua mahasiswa berada di pondok pesantren, maka ada ustadz dan pengurus pondok yang menjelaskan bahwa terdapat beasiswa belajar di Indonesia, Sudan, Mesir dan beberapa negara di Timur Tengah. Mereka yang belum paham tentang informasi tersebut langsung mencari informasi melalui internet. Setelah mengetahui bahwa Indonesia merupakan negara yang mayoritas muslim, mereka akhirnya memilih Indonesia sebagai tujuan.

Dari hasil penelitian diketahui bahwa ada beberapa alasan mengapa mereka mengikuti program pendidikan S1 di STAIN Kediri. Alasan terbesar adalah ingin mendapatkan pengalaman, selain itu juga ada beberapa alasan yang bisa dilihat di tabel 2.

Tabel 2. Motivasi mahasiswa Thailand belajar ke STAIN Kediri, Indonesia

\begin{tabular}{|c|l|}
\hline No & \multicolumn{1}{|c|}{ Motivasi } \\
\hline 1 & Ingin mencari pengalaman \\
2 & Ingin belajar bahasa \& budaya Indonesia \\
3 & Ada kesamaan bahasa yakni bahasa melayu \\
4 & Karena faktor agama, di Indonesia mayoritas Islam \\
5 & Karena wilayah Indonesia lebih dekat dengan Thailand \& biaya hidup \\
& terjangkau \\
6 & Di Indonesia relatif aman dan kelihatan maju \\
7 & Mendapat beasiswa \\
8 & Dari pengalaman alumni yang pernah belajar dari Indonesia menjadi \\
& lebih berani dan banyak yang jadi pemimpin \\
\hline
\end{tabular}

Hampir semua informan tidak pernah tinggal di luar negeri sehingga dengan mengikuti program pendidikan di Indonesia ini merupakan kesempatan yang tidak boleh disia-siakan untuk mencari pengalaman. Indonesia sebagai negara tujuan memiliki alasan khusus mengapa dipilih oleh para informan selain Indonesia sebagai negara yang ditawarkan oleh Ustadz mereka atau ada akses ke sana. Selain itu 
Indonesia dirasa dekat dengan daerah asal mereka, terjangkau dalam hal biaya dibandingkan di negara lain, sekolah di Indonesia banyak sekali, orang-orangnya berani, ramah dan aman dari ancaman kerusuhan. Orang Indonesia juga menggunakan bahasa Melayu, sehingga masih dapat dimengerti oleh mereka. Di Indonesia, seluruh mahasiswa Thailand yang bersekolah di STAIN Kediri angkatan 2013/2014 mendapat beasiswa untuk pendidikan saja sedangkan untuk biaya hidup dan lain-lain menggunakan biaya sendiri. Maka dari itu mereka lebih memilih memasak sendiri karena murah dan bisa sesuai selera.

Sesuatu yang bisa memberi dorongan kepada seseorang untuk melakukan suatu tindakan bisa disebut dengan motivasi. Seperti yang diungkapkan oleh Wahjosumidjo (1994:174), motivasi merupakan "suatu proses psikologis yang mencerminkan interaksi antara sikap, kebutuhan, persepsi dan keputusan yang terjadi pada diri seseorang". Motivasi ini bisa disebabkan oleh faktor dari dalam diri seseorang yang disebut dengan faktor intrinsik misalnya berupa kepribadian, sikap, pengalaman dan pendidikan atau berbagai harapan, cita-cita yang menjangkau masa depan. Sedangkan motivasi yang disebabkan oleh faktor dari luar diri seseorang disebut faktor ekstrinsik. Faktor ini dapat ditimbulkan oleh berbagai sumber bisa karena pengaruh pemimpin, kolega atau faktor-faktor lain yang sangat kompleks. Motivasi yang kuat maka seseorang akan terdorong untuk lebih kuat melakukan sesuatu atau mengambil sikap tertentu. Motivasi bisa ditumbuhkan melalui pemberian hadiah, pujian, rasa kebanggaan pribadi, atau rasa kedaerahan, kebangsaan dan sebagainya. Motivasi sangat diperlukan dalam usaha menumbuhkan dan meningkatkan partisipasi masyarakat dalam pembangunan (Priyatna, 1996:15).

Selaras dengan teori tersebut bahwa motivasi mahasiswa Thailand menempuh pendidikan di STAIN Kediri adalah beragam. Motivasi yang mendorong mahasiswa Thailand belajar ke Indonesia khususnya di STAIN Kediri adalah adalah faktor instrinsik (ingin mendapatkan pengalaman baru, ingin belajar bahasa dan budaya Indonesia) dan faktor ekstrinsik (mendapatkan beasiswa, Indonesia dekat, biaya hidup di Indonesia terjangkau, Indonesia aman \& mayoritas muslim, kesamaan bahasa yakni bahasa melayu, pengalaman dari alumni yang pernah belajar di Indonesia). 
Menurut W.I Thomas dan Florian ada beberapa motif sosiogenis yang membentuk perilaku manusia yaitu:1. Keinginan memperoleh pengalaman baru; 2 . Keinginan mendapatkan respon; 3. Keinginan akan pengakuan dan 4. Keinginan akan rasa aman (Rakhmat, 2005:37). Dari data di atas terlihat bahwa sebagian besar dari informan termotivasi mengikuti program pendidikan di STAIN Kediri karena ingin mendapatkan pengalaman baru. Mereka ingin merasakan kehidupan di negara lain sesama dalam wilayah Asia dan mengenal budaya lain dengan langsung tinggal dan berinteraksi dengan masyarakat setempat. Hal in juga sesuai dengan motif sosiogenesis yang pertama yang disampaikan oleh W.I Thomas dan Florian tersebut yakni mendapatkan pengalaman baru. Menurut Melvin H.Marx (dalam Rakhmat, 2005:37) disebutkan juga bahwa "secara naluriah manusia adalah makhluk yang selalu ingin tahu atau curiousity sehingga ini mendorong manusia untuk terus bergerak dan menjelajahi tempat-tempat baru". Demikian juga dengan mahasiswa Thailand yang belajar di STAIN Kediri ini ingin belajar di Indonesia tepatnya di STAIN Kediri ini karena untuk mendapatkan pengalaman yang baru yang nantinya bisa dibagikan pengalamannya tersebut ketika kembali ke Thailand.

Bisa dikatakan bahwa karena keinginan untuk mendapatkan pengalaman baru serta rasa ingin tahu lebih mendominasi dalam pengambilan keputusan memilih belajar ke Indonesia khususnya STAIN Kediri. Hal ini disebabkan karena semua responden berusia cukup muda antara 20 -24 tahun sebanyak $80 \%$ dan berusia antara 25-29 tahun sebesar 20\% sehingga keinginan untuk menunjukkan eksistensi diri sangat besar. Mereka merasa masih muda dan adalah waktunya untuk mendapatkan banyak pengalaman hidup, hal ini juga sesuai dengan motif sosiogenis yang ketiga yaitu keinginan untuk mendapatkan pengakuan.

Selain itu motif sosiogenis menurut Abraham Maslow (dalam Rakhmat, 2005:37) juga menyebutkan motif yang membentuk perilaku manusia adalah (1). Kebutuhan akan rasa aman (safety needs) (2). Kebutuhan akan ketertarikan dan cinta atau belongingness and love needs); (3). Kebutuhan akan penghargaan atau esteem needs; (4). Kebutuhan akan pemenuhan diri atau self actualization. Motif pertama dan kedua rupanya sangat sesuai dengan hasil penelitian terutama yang terkait motivasi yaitu karena negara Indonesia relatif aman tidak seperti di negaranya di wilayah Pattani yang rawan konflik seperti yang dikatakan oleh informan yang bernama Sobree 
Dorloh mengatakan "karena Indonesia itu di sana terkenal orang-orangnya tidak ada konflik antar agama dan juga solidaritas antar umat beragama itu tinggi”.

Hal ini diperkuat pula oleh pernyataan Tamy salah satu mahasiswa yang pernah KKN di wilayah Pattani tentang kondisi wilayah Pattani setelah mewawancarai Ustadz Husni bahwa keterpurukan bangsanya (Pattani) sebab jajahan bangsa Thailand. Sesungguhnya Pattani dulunya adalah negeri yang merdeka, namun sejak Thailand mengambil alih kekuasaan atas bangsa ini, semua orang terpuruk. Salah satu dampaknya terjadinya kemerosotan ilmu pengetahuan terutamanya dalam bidang bahasa, sebab bentuk penjajahan bangsa Thailand kini tidak lagi hanya berupa bom dan bedil yang diluncurkannya, namun sudah merambah ke dalam dunia pendidikan.

\section{Culture Shock Mahasiswa Thailand di Lingkungan Kediri}

Menurut sebagian besar informan, di awal kedatangan masalah klise bagi mahasiswa asing adalah soal iklim, makanan, budaya, dan bahasa walaupun masalah bahasa ini tidak begitu dominan karena secara bahasa ada kesamaan mereka menggunakan bahasa Melayu namun tidak sepenuhnya mereka memahami betul bahasa Indonesia. Demikian halnya yang dialami oleh mahasiswa asal Thailand tersebut saat datang di kampus STAIN Kediri. Reaksi semua informan saat tiba di Indonesia adalah senang. Seperti yang diungkapkan oleh Muhammad Zulgiflee Rehreh salah satu mahasiswa Thailand ini mengatakan "Alhamdulillah bisa di sini, senang bisa di sini karena orangnya baik" yang disetujui oleh informan yang lain yang merasa senang walaupun juga ada yang awalnya merasa sedih dan kangen karena jauh dari orang tua. Meski mereka semua merasa kagum namun ada juga sedikit rasa bingung dan gugup karena masih merasa asing dengan lingkungan baru. Ternyata mahasiswa Thailand ini mengalami homesick sampai culture shock. Perasaan bomesick lebih disebabkan oleh kerinduan dengan keluarga, rasanya jauh dari rumah karena belum pernah ke luar negeri. Seperti yang disampaikan oleh Abdullah Hentam bahwa "saya pertama kali datang ke Indonesia rasanya jauh dari rumah, rasanya takut, karena belum pernah ke luar negeri walaupun dekat'. Bahkan ada juga yang mengaku sampai jatuh sakit pada saat awal datang ke Indonesia sampai opname ke rumah sakit selama 2 hari karena cuaca yang terlalu dingin. 
Culture Shock yang dialami mahasiswa Thailand dalam berbagai hal seperti: cuaca, makanan dan kebiasaan sehari-hari, pergaulan, pakaian, kegiatan sosial keagamaan (seperti: perayaan hari raya, yasinan) yang berbeda dengan di Thailand. Contohnya: saat mereka berada di Ponpes Al-Amien hanya dalam kurun waktu satu bulan dikarenakan mereka merasa tidak cocok dengan keadaan di pesantren. Ada yang beralasan tidak cocok dengan makanan, mandi harus mengantri, banyak santri yang berbicara bahasa jawa, dan jauh dari kampus. Mereka merasa nyaman semenjak menempati kontrakan tersebut karena dapat melakukan kegiatan sesuka mereka. Mereka mengaku dapat memasak masakan Thailand sendiri di kontrakan.

Mengenai budaya yang ada di Kediri sempat membuat mereka kaget dan harus beradaptasi. Banyak hal-hal yang berbeda dengan Thailand seperti pakaian, rutinan yasinan, hari raya, hingga pernikahan. Dalam hal pakaian khususnya wanita membuat mereka kaget karena di Kediri warga muslim dan non muslim sangat sulit dibedakan. Di sini banyak muslim yang tidak berkerudung. Berbeda dengan di Thailand yang apabila seseorang tersebut muslim maka akan mengenakan pakaian muslim.

Selain pakaian, hal yang membuat kaget adalah cara bersalaman. Di Thailand terkenal apabila bukan muhrim maka tidak boleh bersalaman. Berbeda dengan di Indonesia, budaya leluhur adalah harus hormat dengan orang yang lebih tua. Maka cara menyikapi mereka adalah dengan berbicara maaf dan menjelaskan bahwa mereka tidak bisa mengikuti adat tersebut. Menurut mereka banyak yang memahami dan menghargai apabila mereka tidak mau untuk diajak bersalaman dengan lawan jenis.

Selanjutnya adalah 'rutinan'. Pada hari Kamis malam Jumat selalu diadakan pembacaan ayat suci al qur'an - Yasinan. Mereka juga mengikuti rutinan yang dilakukan warga sekitar lingkungan. Berikut penuturan Habibulloh, "saya kaget itu saat baca Yasin. Di sini cepat sekali baca, beda dengan di sana". Ternyata di setiap rutinan di Kediri dan Thailand juga terdapat hidangan. Bedanya di Kediri makanan di taruh pada piring, sedangkan di Thailand dibentuk kelompok-kelompok yang setiap kelompok berjumlah lima orang. Nantinya setiap kelompok diberi wadah berisi makanan dan dimakan bersama-sama. 
Mereka lama-kelamaan merasa bahwa budaya Indonesia tidak jauh berbeda dengan Thailand. Hingga rata-rata mereka membutuhkan waktu kurang lebih satu hingga tiga bulan untuk beradaptasi dengan lingkungan sekitar. Pada waktu hari raya setelah sholat dilaksanakan apabila di Thailand, hal yang dilakukan adalah bersalaman di masjid dengan tetangga semua kemudian ziarah ke rumah saudara yang jauh. Kalau di Indonesia juga bersalaman namun tetap harus mengunjungi rumah tetangga lagi dan berkunjung ke saudara yang jauh.

Mahasiswa Thailand merasa senang sekali bisa tinggal di Kediri. Tetapi ada beberapa yang membuat mereka tidak senang karena ada beberapa tetangga yang mengira anak Thailand itu kaya padahal sama dengan warga di sini. Yang membedakan adalah kalau di Thailand semua mahal kalau di sini murah. Dari situlah banyak yang berpendapat bahwa anak Thailand kaya. Tak jarang mereka ditipu oleh beberapa pedagang dengan menaikkan harga dari yang semestinya. Namun masih banyak juga tetangga yang memang baik hati. Mereka merasa senang dan betah karena di sini juga banyak tempat wisata yang dapat mereka kunjungi seperti Klothok, Mall, Gumul, Jalan Dhoho dan Alun-alun Kediri.

Dari hasil penelitian diketahui bahwa semua informan mengalami culture shock sebagai kognsekuensi budaya ketika sesorang dihadapkan pada suatu tempat yang baru dengan budaya baru pula. Culture shock dialami oleh mahasiswa Thailand terutama berkaitan dengan makanan, gaya hidup (kebiasaan-kebiasaan, pergaulan), cuaca, lingkungan (kegiatan sosial keagamaan). Menurut Furnham dan Bochner, "culture shock adalah ketika seseorang mengenal kebiasaan-kebiasaan sosial dari kultur baru atau jika ia mengenalnya maka ia tidak dapat tidak bersedia menampilkan perilaku yang sesuai dengan aturan-aturan itu" (Dayakisni dan Yuniardi, 2008:187).

Sementara itu Kalvero Oberg menyatakan culture shock (gegar budaya) ditimbulkan oleh kecemasan yang disebabkan oleh kehilangan tanda-tanda dan lambang-lambang dalam pergaulan sosial. Tanda-tanda tersebut meliputi seribu satu cara yang kita lakukan dalam mengendalikan diri sendiri dalam menghadapi situasi sehari-hari. Petunjuk-petunjuk ini yang mungkin dalam bentuk-bentuk kata-kata, isyarat-isyarat, ekspresi wajah, kebiasaan-kebiasaan, atau norma-norma, kita peroleh sepanjang perjalanan hidup sejak kecil. Bila seseorang memasuki suatu budaya asing, semua atau hampir semua petunjuk ini lenyap (Mulyana dan Rakhmat, 2006:174). 
Hasil penelitian menunjukkan bahwa para informan merasa kehilangan cues atau tanda-tanda yang dikenalnya terutama berkaitan dengan makanan. Pada awal tinggal di Kediri di Pondok Pesantren selama satu bulan mereka merasa tidak nyaman karena ada yang beralasan tidak cocok dengan makanan karena lauknya tahu tempe yang berbeda dengan selera mereka yang biasa makan seafood karena daerah mereka memang dekat dengan pantai,mandi harus mengantri, banyak santri yang berbicara bahasa jawa, dan jauh dari kampus. Mereka merasa nyaman semenjak menempati kontrakan tersebut karena dapat melakukan kegiatan sesuka mereka. Mereka mengaku dapat memasak masakan Thailand sendiri di kontrakan.

Pada umumnya masyarakat Thailand memiliki dua makanan pokok, pada wilayah Thailand utara (dataran atas) Ketan menjadi makanan pokok mereka. Sedangkan di wilayah Thailand selatan makanan pokok mereka sama dengan masyarakat Indonesia yakni nasi. Menu masakan di Thailand tidak jauh berbeda dengan Indonesia seperti gulai, sayur sup, sayur bening, rendang dan sebagainya. Hanya saja nama-nama masakannya bebeda dengan negara kita. Ciri khas dari masakan Thailand adalah rasanya yang sangat kuat. Baik rasa asin, manis dan asam.

Culture shock yang dialami oleh mahasiswa Thailand ini dalam hal gaya hidup berkaitan dengan kebiasaan dan pergaulan. Tiap individu memiliki gaya hidup yang berbeda satu sama lain, namun kesamaan kebudayaan yang dimiliki membentuk gaya hidup tidak jauh berbeda satu sama lain. Secara umum gaya hidup masyarakat Pattani dalam kesehariannya, bila dilihat gaya makan mereka tergolong mewah karena sekali makan pada umumnya masyarakat Patani terbiasa memakan lebih dari tiga menu masakan dan tidak pernah terlepas dari seafood. Namun jika di lihat penampilan tampak sederhana, begitupun dalam hal bersosial dengan orang lain sangat ramah.

Dalam hal pakaian khususnya wanita membuat mereka kaget karena di Kediri warga muslim dan non muslim sangat sulit dibedakan. Di sini banyak muslim yang tidak berkerudung. Berbeda dengan di Thailand yang apabila seseorang tersebut muslim maka akan mengenakan pakaian muslim. Di sini banyak muslim yang tidak berkerudung. Berbeda dengan di Thailand yang apabila seseorang tersebut muslim maka akan mengenakan pakaian muslim. Selain pakaian, hal yang membuat kaget adalah cara bersalaman. Di Thailand terkenal apabila bukan muhrim maka tidak boleh bersalaman. Berbeda dengan di Indonesia, budaya leluhur adalah harus hormat 
dengan orang yang lebih tua. Maka cara menyikapi mereka adalah dengan berbicara maaf dan menjelaskan bahwa mereka tidak bisa mengikuti adat tersebut. Menurut mereka banyak yang memahami dan menghargai apabila mereka tidak mau untuk diajak bersalaman dengan lawan jenis.

Faktor cuaca juga menjadi masalah klise yang dialami oleh satu orang mahasiswa Thailand yang baru pertama kali datang ke Indonesia. Bahkan ada juga yang mengaku sampai jatuh sakit pada saat awal datang ke Indonesia sampai opname ke rumah sakit selama 2 hari karena cuaca yang terlalu dingin. Walaupun kenyataannya cuaca di wilayah Pattani tidak jauh berbeda dengan Indonesia, memiliki tiga musim pada tiap tahunnya yakni musim panas (kemarau) dan musim dingin dan musim hujan. Pada musim panas/kemarau kondisi siang hari terasa sangat panas, tidak jauh berbeda dengan suhu kota-kota besar di Indonesia.

\section{Kesimpulan}

Motivasi yang mendorong mahasiswa thailand belajar ke Indonesia khususnya di STAIN Kediri adalah faktor instrinsik antara lain: ingin mendapatkan pengalaman baru, ingin belajar bahasa dan budaya Indonesia dan faktor ekstrinsik yakni: mendapatkan beasiswa, Indonesia dekat, biaya hidup di Indonesia terjangkau, Indonesia aman \& mayoritas muslim, kesamaan bahasa (rumpun Melayu), pengalaman dari alumni yang pernah belajar di Indonesia.

Culture shock dialami oleh mahasiswa Thailand terutama berkaitan dengan makanan, gaya hidup (kebiasaan-kebiasaan, pergaulan), cuaca, dan kegiatan sosial keagamaan. Saat mengalami culture shock sebagian besar mahasiswa Thailand ini bisa mengatasinya sendiri namun sebagian lagi membutuhkan bantuan orang lain seperti teman. Diperlukan proses dan latihan untuk dapat menyesuaikan budaya di Kediri baik terkait dengan cuasa, makanan, bahasa, dan gaya hidup masyarakat setempat, tiap informan membutuhkan masa yang berbeda-beda yakni sekitar satu sampai tiga bulan mereka bisa beradaptasi dan berakulturasi dengan budaya Kediri. 


\section{Referensi}

Creswell, John W. (2012). Research Design Pendekatan Kualitatif, Kuantitatif dan Mixed. Yogyakarta: Pustaka Pelajar

Dayakisni, T. dan Yuniardi, S. (2008) Psikologi Lintas Budaya. Malang : UMM Press

Devito, Joseph A. (1997). Komunikasi Antara Manusia. (Alih Bahasa: Ir. Agus Maulana, MSM). Jakarta: Profesional Books

Indra Dewi, Sulih. (2009) Culture Shock dan Akulturasi dalam Lingkungan Budaya Belanda. Malang: Universitas Tribhuwana Tunggadewi

Khalil, Ahmad. (2008) Islam Jawa Sufisme dalam Etika dan Tradisi Jawa. (Malang: UIN Malang Press

Koentjaraningrat. (1986) Metode-metode Penelitian Masyarakat. Jakarta: PT. Gramedia

Liliweri, Alo. (1994). Perspektif Teoritis Komunikasi Antar Pribadi. Bandung: PT. Citra Aditya Bakti

Littlejohn, Stephen W. (2001). Theories of Human Communication. New Mexico: Wadsworth, Thomson Learning

Mulyana, Deddy. (2001). Metodologi Penelitian Kualitatif: Paradigma Baru Ilmu Komunikasi dan Ilmu Sosial Lainnya. Bandung: Remaja Rosdakarya (2004). Ilmu Komunikasi: Suatu Pengantar. Bandung: PT. Remaja Rosda Karya

Mulyana, Deddy dan Jalaluddin Rakhmat. (2006). Komunikasi AntarBudaya. Bandung: PT. Remaja Rosdakarya

Moleong, Lexy J. (2001). Metodologi Penelitian Kualitatif. Bandung: PT. Remaja Rosdakarya

Nasrullah, Rully. (2012). Komunikasi Antarbudaya Di Era Budaya Siber. Jakarta: Kencana Prenada Media Group

Purwasito, Andrik. (2003). Komunikasi Multikultural. Surakarta: Muhammadiyah University Press

Rakhmad, Jalaluddin. (1998). Metode Penelitian Komunikasi. Bandung: PT. Remaja Rosdakarya (1991). Psikologi Komunikasi. Edisi Revisi. Bandung: PT. Remaja Rosdakarya 
Santosa, Imam Budhi. (2012). Spiritualisme Jawa Sejarah Laku dan Intisari Ajaran. Yogyakarta: Memayu Publishing

Sugiyono. (2013). Metode Penelitian Kuantitatif, Kualitatif dan R \& D. Bandung: Alfabeta Syarbaini dan Rusdiyanto. (2009). Dasar-dasar Sosiologi. Yogyakarta: Graha Ilmu

Sutopo, H.B. (2002). Metode Penelitian Kualitatif: Dasar Teori dan Terapannya dalam Penelitian. Surakarta: Sebelas Maret University Press 